\title{
Pemanfaatan Limbah Kulit Mangga di Kota Cirebon
}

\author{
Farida Mardhatilla, Edy Hartono, Firman Hidayat \\ Universitas Swadaya Gunung Jati \\ Email: fmardhatilla@gmail.com
}

\begin{abstract}
ABSTRAK
Mangga merupakan salah satu buah unggulan di Kabupaten Cirebon. Produksi Mangga pada tahun 2018 di Kabupaten Cirebon mencapai 554.767 kuintal. Tingginya produksi mangga di Kabupaten Cirebon merangsang pertumbuhan industri olahan mangga di Kabupaten Cirebon. Industri olahan mangga umumnya hanya menggunakan daging mangga, sehingga kulit dan biji mangga merupakan limbah dari industri tersebut. Limbah kulit mangga mencapai 10\% dari total buah mangga. Kulit mangga memiliki kandungan pektin yang cukup tinggi, sehingga kulit mangga dapat dimanfaatkan sebagai bahan dasar pembuatan permen. Kandungan pektin pada kulit mangga selain dapat membentuk gel juga dapat menurunkan kolesterol. Pemanfaatan kulit mangga menjadi permen dilakukan oleh kelompok wanita tani "Srikandi" yang berlokasi di Kabupaten Cirebon. Pemanfaatan limbah kulit mangga ini memberikan nilai tambah dan dapat meningkatkan penghasilan. Keuntungan yang diperoleh pada 5 kali produksi permen adalah sebesar Rp 3.500.000,-
\end{abstract}

Kata Kunci : Kulit mangga, permen, nilai tambah

\begin{abstract}
Mango is one of the leading fruits in Cirebon Regency. Mango production in 2018 in Cirebon Regency reached 554,767 quintals. The high mango production in Cirebon Regency stimulates the growth of the mango processing industry in Cirebon Regency. The mango processing industry generally only uses mango meat, so mango peels and seeds are waste from the industry. Mango peel waste reaches $10 \%$ of the total mango. The mango peel has a high pectin content, so the mango peel can be used as a base for making candy. Besides being able to form a gel, the pectin content in mango peels can also lower cholesterol. Utilization of mango peels into candy is carried out by the "Srikandi" farmer women group located in Cirebon Regency. Utilization of mango peel waste provides added value and can increase income. The profit earned on 5 candy production times is IDR 3. 500,000
\end{abstract} Keywords: Mango peel, candy, added value

\section{PENDAHULUAN}

Mangga merupakan salah satu komoditas buah yang memiliki kontribusi terbesar di Indonesia. Peningkatan luas panen mangga setiap tahun mulai tahun 2016 hingga 2018 juga beriringan dengan jumlah produksi yang terus meningkat. Menurut data BPS, pada tahun 2016 jumlah produksi mangga di Indonesia sebesar 1,8 juta ton. Kemudian pada tahun 2017 meningkat menjadi 2,2 juta ton dan terus meningkat di tahun 2018 menjadi sebanyak 2,6 juta ton. Kabupaten Cirebon merupakan salah satu kabupaten penghasil mangga terbesar di Provinsi Jawa Barat, produksi mangga tahun 2017 di Kabupaten Cirebon mencapai 384.173 kuintal (Kabupaten Cirebon dalam Angka, 2018). Total produksi mangga yang dihasilkan oleh Kabupaten Cirebon, sekitar 10\% merupakan mangga dengan kategori grade $\mathrm{C}$ yang tidak memenuhi permintaan pasar modern. Kondisi tersebut sesuai dengan penelitian Rustiana (2008) yang menyatakan bahwa di Kabupaten Cirebon, pada setiap musim panen mangga terdapat rata-rata $10 \%$ dari total panen mangga grade $C$ yang tidak laku dijual dan akhirnya terbuang dikarenakan umur simpan buah mangga yang singkat. Sulistyowati, dkk (2016) menyatakan bahwa sekitar $90 \%$ hasil produksi mangga dapat dikategorikan grade $\mathrm{A}$ dan B sedangkan sisanya 10\% merupakan mangga dengan kategori grade C yang biasanya disalurkan ke industri pengolahan.

Industri pengolahan mangga banyak terdapat di daerah Kabupaten Cirebon, hal ini disebabkan melimpahnya produksi mangga yang tidak terjual di pasar, terutama mangga yang memiliki grade $\mathrm{C}$. Selain hal tersebut, mangga olahan juga lebih banyak diminati dan 
dapat meningkatkan nilai jual ke konsumen. Salah satu agroindustri pengolahan mangga di Cirebon adalah UKM CV. Kresna Multi Produk yang melakukan pengolahan mangga menjadi jus dalam kemasan. UKM CV. Kresna Multi Produk merupakan salah satu anggota Kelompok Wanita Tani (KWT) Srikandi yang berdomisili di Cirebon. Setiap kali produksi, CV. Kresna Multi Produk hanya mengambil daging buah mangga, sedangkan kulit dan biji mangga biasanya hanya sebagai limbah. Hasil limbah kulit mangga sangat besar pada industri pengolahan mangga. Berat kulit mangga mencapai $10 \%$ dari total buah. Umumnya kulit mangga dibuang begitu saja sebagai limbah, padahal kulit mangga memiliki senyawa kimia pektin.

Pektin merupakan polisakarida penguat tekstur dalam sel tanaman yang terdapat diantara selulosa dan hemiselulosa. Bersama - sama selulosa dan hamiselulosa membentuk jaringan dan memperkuat dinding sel tanaman. Pektin banyak digunakan dalam industri pangan karena kemampuannya membentuk gel yang merupakan bahan dasar pembentuk jelli dan pengawetan buah. Berdasarkan kemampuan tersebut, maka kulit mangga masih sangat berpotensi menjadi suatu produk, yaitu permen. Adanya pengoloahan kulit mangga menjadi permen merupakan salah satu alternatif yang baik untuk meminimalisir limbah kulit mangga dan menambahkan nilai tambah yang menjadi sumber penghasilan tambahan.

\section{BAHAN DAN METODE}

Pelaksanaan pengabdian dilakukan di Kecamatan Harjamukti Kota Cirebon pada bulan Agustus 2020. Peserta pengabdian adalah ibu - ibu Kelompok Wanita Tani (KWT) "SRIKANDI" yang bergerak di pengolahan hasil pertanian dengan jumlah 10 orang.

\section{Metode Kegiatan}

Kegiatan pengabdian ini berupa pelatihan pengolahan permen dari kulit mangga. Pengolahan permen kulit mangga ini didasari adanya kandungan pektin pada kulita mangga yang dapat membentuk gel sehingga cocok dibuat menjadi permen. Adapun cara pengolahan kulit mangga sebagai berikut :

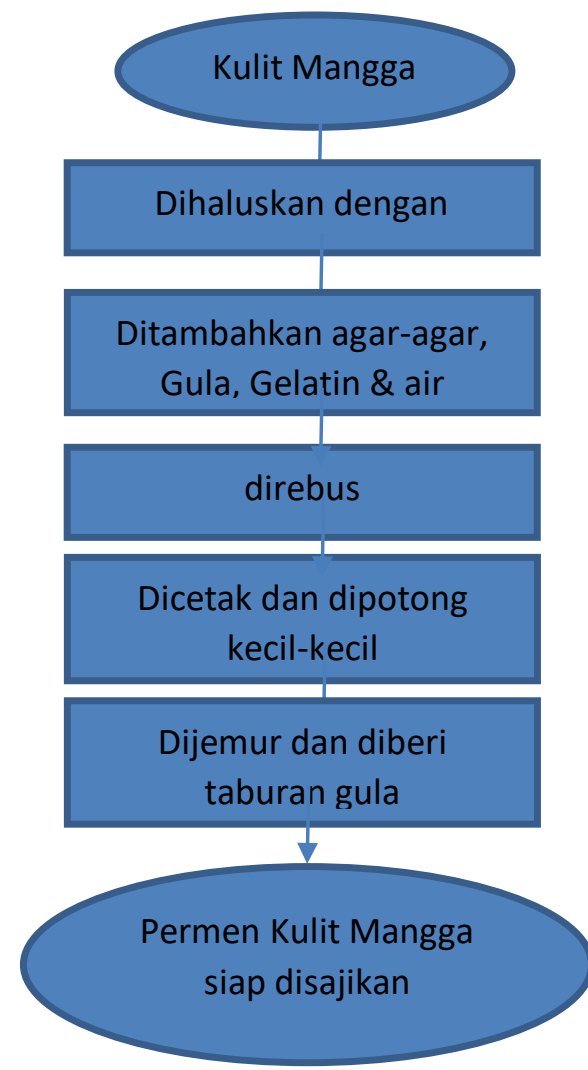

(Gambar 1. Tahapan Pembuatan Permen Kulit Mangga). 


\section{HASIL DAN PEMBAHASAN}

Pemanfaatan kulit mangga sebagai bahan pangan sangat potensial untuk dikembangkan. Kandungan pektin yang ada pada kulit mangga mampu membentuk gel sehingga berpengaruh baik pada rasa maupun tekstur permen. Selain berfungsi sebagai pembentuk gel, pektin juga berfungsi menurunkan kolesterol (Umam,dkk 2020).

Hasil olahan permen kulit mangga, telah dipasarkan oleh anggota kelompok wanita tani "Srikandi" dan mendapat respon yang cukup baik di pasar.

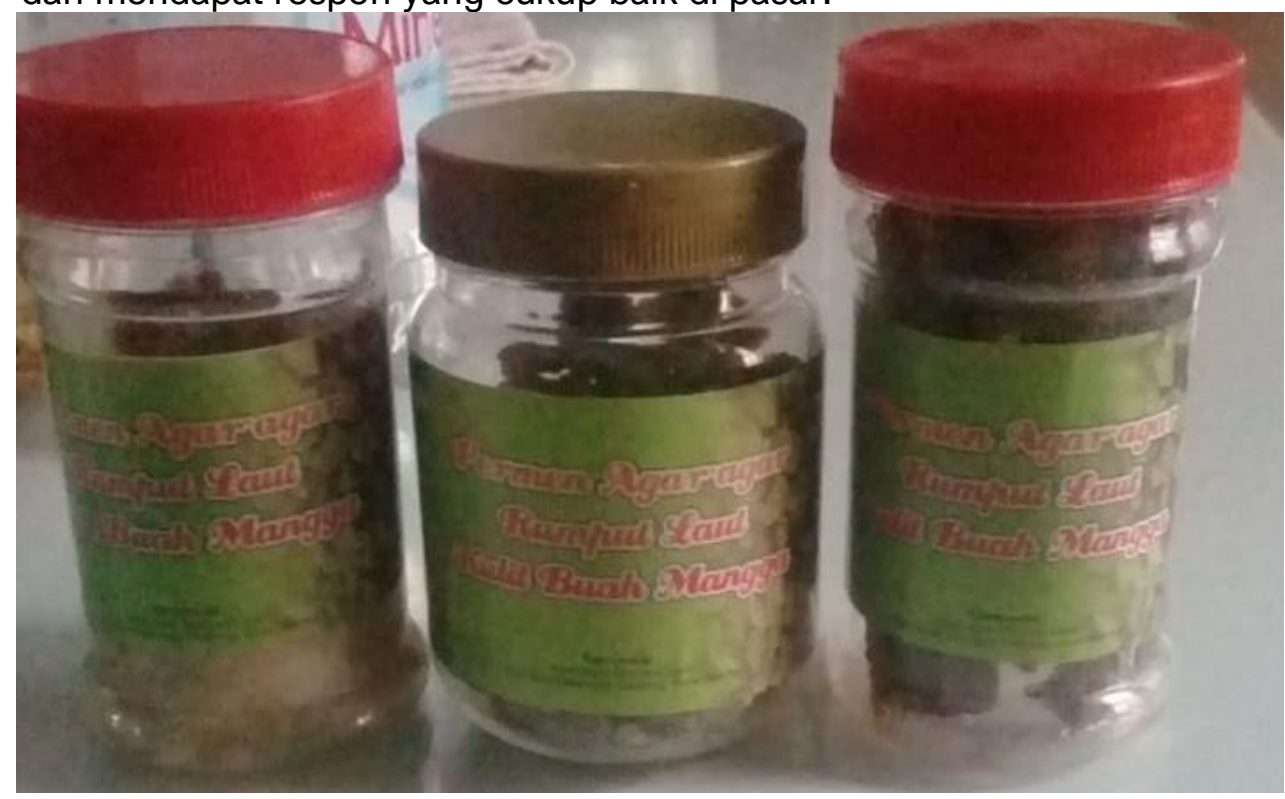

(Gambar 2. Permen Kulit Mangga siap dipasarkan)

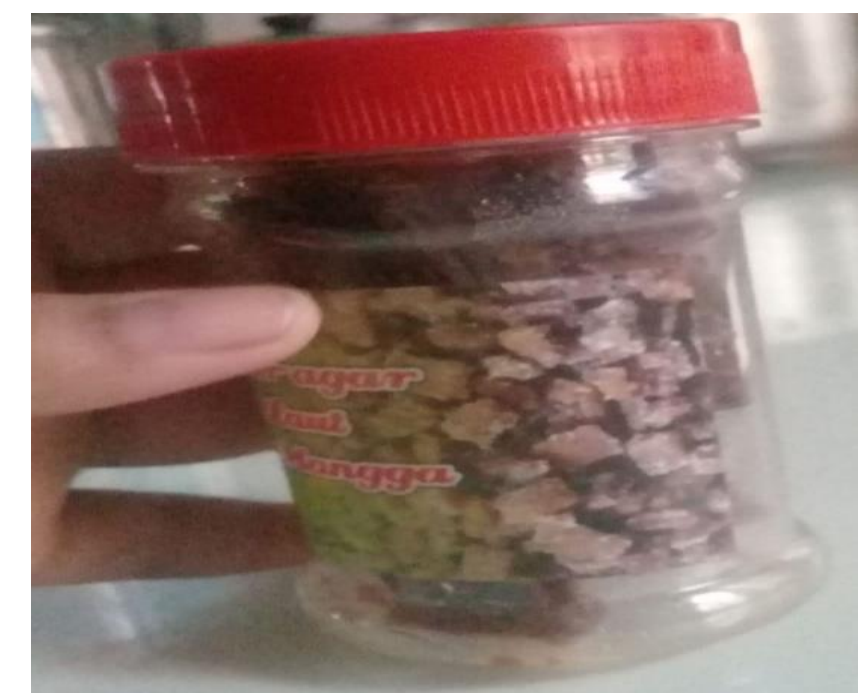

(Gambar 3. Permen Kulit Mangga diberi taburan Gula)

Adanya kandungan pektin membuat tekstur permen kulit mangga lebih kenyal dan disukai oleh berbagai kalangan. Pemanfaatan kulit mangga sebagai permen memberikan nilai tambah yang dapat meningkatkan penghasilan. Analisis perhitungan nilai tambah pada permen kulit mangga dapat dilihat pada tabel 1.berikut :

Tabel 1. Perhitungan Nilai Tambah Permen Kulit Mangga Selama Satu Bulan

\begin{tabular}{llc}
\hline No & Variabel & Nilai \\
\hline I. & Output, Input dan Harga & \\
\hline 1 & Output $(\mathrm{Kg})$ & 30
\end{tabular}




\begin{tabular}{cll}
\hline No & Variabel & Nilai \\
2 & Input (Kg) & 25 \\
3 & Tenaga Kerja (HOK/bulan) & 5 \\
4 & Faktor Konversi & 0,5 \\
5 & Koefisien Tenaga Kerja & 0,2 \\
6 & Harga Output (Rp/Kg) & $116.666,6$ \\
& & \\
7 & Upah Tenaga Kerja Langsung (Rp/HOK) & 20.000 \\
\hline II. & Penerimaan dan Keuntungan & \\
\hline 8 & Harga Bahan Baku (Rp/Kg) & 0 \\
9 & Sumbangan Input Lain (Rp/Kg) & 30.416 \\
10 & Nilai Output (Rp/Kg) & $58.333,33$ \\
11 & a. Nilai Tambah (Rp/Kg) & $27.917,33$ \\
& b. Rasio Nilai Tambah (\%) & $47,86 \%$ \\
12 & a. Pendapatan Tenaga Kerja Langsung (Rp/Kg) & 4.000 \\
& b. Pangsa Tenaga Kerja (\%) & $14,32 \%$ \\
13 & a. Keuntungan (Rp/Kg) & $23.917,33$ \\
& b. Tingkat Keuntungan (\%) & $85,67 \%$ \\
\hline III. & Balas Jasa Pemilik Faktor-Faktor Produksi \\
\hline 14 & Marjin (Rp/Kg) & $58.333,33$ \\
& a. Pendapatan Tenaga Kerja Langsung (\%) & $6,86 \%$ \\
& b. Sumbangan Input Lain (\%) & $52,14 \%$ \\
& c. Keuntungan Pemilik UMKM (\%) & $41 \%$ \\
\hline
\end{tabular}

Dari perhitungan diatas dapat diketahui tingkat keuntungan penjualan permen kulit mangga sebesar $85,67 \%$. Keuntungan yang peroleh selam satu bulan dengan 5 kali proses produksi adalah sebesar Rp 3.500.000,10 dengan rasio kelayakan sebesar 2,07. Nilai tambah yang diperoleh per $1 \mathrm{~kg}$ kulit manga adalah sebesar Rp 27.917,33..

\section{KESIMPULAN DAN SARAN Kesimpulan}

Pemanfaatan kulit mangga sebagai permen dapat meningkatkan nilai tambah pada mangga tersebut dan memberikan keuntungan tambahan bagi anggota kelompok wanita tani "Srikandi". Kulit mangga yang awalnya merupakan limbah dan cukup banyak jumlahnya dapat diolah kembali menjadi produk yang bernilai jual.

\section{Saran}

Pengolahan permen kulit mangga hendaknya dikaji lebih dalam agar mendapat bentuk dan rasa yang lebih sempurna dengan melakukan uji coba perbandingan kulit mangga dan bahan pendukung lainnya

\section{DAFTAR PUSTAKA}

Anitasari, S., Sunartomo, A. F., \& Ridjal, J. A. 2014. Manajemen Rantai Pasokan Produk Olahan Mangga Arum Manis di Kabupaten Sitobondo.Berkala IImiah Pertanian

Asfia, Nora. 2013. Analisis Pendapatan, Nilai Tambah, dan Prospek Pengembangan Industri Kecil Tapioka di Jawa Barat ( Studi Kasus Desa Pasir Jambu Kecamatan Sukaraja Kabupaten Bogor). Skripsi pada Departemen Agribisnis, Fakultas Ekonomi dan Manajemen, Institut Pertanian Bogor, Bogor.

BPS Provinsi Jawa Barat 2018. Jawa Barat dalam Angka 2018. Badan Pusat Statistik Provinsi Jawa Barat. 
Direktorat Jenderal Hortikultura. 2017. Statistik Produksi Hortikultura 2016. Jakarta. SKementrian Pertanian.

Maulidah, Silvana, and Fenny Kusumawardani.2011. Nilai Tambah Agroindustri Belimbing Manis (Averrhoa Carambola L.) dan Optimalisasi Output Sebagai Upaya Peningkatan

Pendapatan." Agricultural Socio- Economics Journal Vol 11.No.1: 19.

Mutmainnah, Lutfiana, Usman Effendi, and Ika Atsari Dewi.2017. Analisis Kelayakan Teknis dan Finansial Puree Mangga Podang Urang Pada Skala Industri Kecil Menengah (Studi Kasus Pada IKM KWT Budidaya Tiron Makmur Banyakan, Kediri)." Industria: Jurnal Teknologi dan Manajemen Agroindustri Vol 3. No 3: 127-137

Noerkumala, N. M., Suwandari, A., \& Supriono, A. 2016. Nilai Tambah dan Strategi Pengembangan Agroindustri Belimbing Kota Blitar. Pamator Journal, Vol 9 Nomor 1 Hal 41-51

Rustiana, Iswanti Noor.2008. Analisis Kelayakan Usaha Pengolahan Puree Mangga (Mangifera indica L.) Departemen Sosial Ekonomi Pertanian, Fakultas Pertanian, Institut Pertanian Bogor, Bogor.

Sulistyowati, Lies, Nur Syamsiah, and Siti Nur Azisah. 2016. Kajian Rantai Pasok Mangga Ke Pasar Ekspor dan Kolaborasi Diantara Pelaku Kemitraan. Jurnal Agribisnis Terpadu Vol 9. No. 1 